Review

\title{
Dynamic Models of Rigid Memory Mechanisms
}

\author{
Florian Ion Tiberiu Petrescu
}

ARoTMM-IFToMM, Bucharest Polytechnic University, Bucharest, (CE), Romania

Article history

Received: 21-10-2018

Revised: $29-10-2018$

Accepted: 19-11-2018

Email: scipub02@gmail.com

\begin{abstract}
Rigid memory mechanisms have played an important role in the history of mankind, contributing greatly to the industrial, economic, social changes in society, thus leading to a real evolution of mankind. Used in automated tissue wars, in cars as distribution mechanisms, automated machines, mechanical transmissions, robots and mechatronics, precision devices and medical devices, these mechanisms have been real support for mankind along the time. For this reason, I considered useful this paper, which presents some dynamic models that played an essential role in designing rigid memory mechanisms.
\end{abstract}

Keywords: Cam Gears, Rigid Memory Mechanisms, Gearboxes, Dynamic Models

\section{Introduction}

The development and diversification of road vehicles and vehicles, especially of cars, together with thermal engines, especially internal combustion engines (being more compact, robust, more independent, more reliable, stronger, more dynamic etc.)., has also forced the development of devices, mechanisms and component assemblies at an alert pace. The most studied are power and transmission trains.

The four-stroke internal combustion engine (fourstroke, Otto or Diesel) comprises in most cases (with the exception of rotary motors) and one or more camshafts, valves, valves and so on.

The classical distribution mechanisms are robust, reliable, dynamic, fast-response and although they functioned with very low mechanical efficiency, taking much of the engine power and effectively causing additional pollution and increased fuel consumption, they could not be abandoned until the present. Another problem was the low speed from which these mechanisms begin to produce vibrations and very high noises.

Regarding the situation realistically, the mechanisms of cam casting and sticking are those that could have produced more industrial, economic, social revolutions in the development of mankind. They have contributed substantially to the development of internal combustion engines and their spreading to the detriment of external combustion (Steam or Stirling) combustion engines.

The problem of very low yields, high emissions and very high power and fuel consumption has been greatly improved and regulated over the past 20-30 years by developing and introducing modern distribution mechanisms that, besides higher yields immediately deliver a high fuel economy) also performs optimal noise-free, vibration-free, no-smoky operation, as the maximum possible engine speed has increased from 6000 to 30000 [rpm].

The paper tries to provide additional support to the development of distribution mechanisms so that their performance and the engines they will be able to further enhance.

Particular performance is the further increase in the mechanical efficiency of distribution systems, up to unprecedented quotas so far, which will bring a major fuel economy.

The current oil and energy reserves of mankind are limited. Until the implementation of new energy sources (to take real control over fossil fuels), a real alternative source of energy and fuel is even "the reduction in fuel consumption of a motor vehicle", whether we burn oil, gas and petroleum derivatives, whether we will implement biofuels first and later hydrogen (extracted from water).

The drop in fuel consumption for a given vehicle type over a hundred kilometers traveled has been consistently since 1980 and has continued to continue in the future.

Even if hybrids and electric motor cars are to be multiplied, let us not forget that they have to be charged with electricity, which is generally obtained by burning fossil fuels, especially oil and gas, in a current planetary proportion of about $60 \%$. We burn oil in large heat plants to warm up, have domestic hot water and electricity to consume and some of that energy is extra and we add it to electric cars (electric vehicles), but the global energy problem is not resolved, the crisis even 
deepens. This was the case when we electrified the railroad for trains, when we generalized trams, trolleybuses and subways, consuming more electric power produced mainly from oil; oil consumption has grown a lot, its price has had a huge leap and we look at how the reserves disappear quickly.

Generally generalizing electric cars (though we are not really ready for this), we will give a new blow to oil and gas reserves.

Fortunately, biofuels, biomass and nuclear power have developed very much lately (currently based on the nuclear fission reaction). These together with the hydroelectric power plants have managed to produce about $40 \%$ of the total energy consumed globally. Only about $2-3 \%$ of global energy resources are produced by various other alternative methods (despite the efforts made so far).

This should not disarm us and abandon the implementation of solar, wind, etc.

However, as a first necessity to further reduce the share of global energy from oil and gas, the first vigorous measures that will need to be pursued will be to increase biomass and biofuels production along with the widening of the number of nuclear power plants (despite some undesirable events, which only show that nuclear fission power plants must be built with a high degree of safety and in no way eliminated from now on and they are still the one that has been so far "a bad evil ").

Alternative sources will take them on an unprecedented scale, but we expect the energy they provide to be more consistent in global percentages so that we can rely on them in a real way (otherwise, we risk that all these alternative energies remain a sort of "fairy tale").

Hydrogen fuel energy "when it starts when it stops" so there is no real time now to save energy through them, so they can no longer be priority, but the trucks and buses could even be implemented now that the storage problems have been partially solved. The bigger problem with hydrogen is no longer the safe storage, but the high amount of energy needed to extract it and especially for its bottling. The huge amount of electricity consumed for bottling hydrogen will have to be obtained entirely through alternative energy sources, otherwise hydrogen programs will not be profitable for humanity at least for the time being. Personally, I think the immediate use of hydrogen extracted from the water with alternative energies would be more appropriate for seagoing vessels.

Maybe just to say that due to his energy crisis (and not just energy, from 1970 until today), the production of cars and cars has increased at an alert pace (but naturally) instead of falling and they have and were marketed and used. The world's energy crisis (in the 1970s) began to rise from around 200 million vehicles worldwide, to about 350 million in 1980 (when the world's energy and global fuel crisis was declared), about 500 million vehicles worldwide and in 1997 the number of world-registered vehicles exceeded 600 million.

In 2010, more than 800 million vehicles circulate across the planet (Frățilă et al., 2011; Pelecudi, 1967; Antonescu, 2000; Comănescu et al., 2010; Aversa et al., 2016a; 2016b; 2016c; 2016d; 2017a; 2017b; 2017c; 2017d; 2017e; Mirsayar et al., 2017; Cao et al., 2013; Dong et al., 2013; De Melo et al., 2012; Garcia et al., 2007; Garcia-Murillo et al., 2013; He et al., 2013; Lee, 2013; Lin et al., 2013; Liu et al., 2013; Padula and Perdereau, 2013; Perumaal and Jawahar, 2013; Petrescu and Petrescu, 1995a; 1995b; 1997a; 1997b; 1997c; 2000a; 2000b; 2002a; 2002b; 2003; 2005a; 2005b; 2005c; 2005d; 2005e, 2016a; 2016b; 2016c; 2016d; 2016e; 2013; 2012a; 2012b; 2011; Petrescu et al., 2009; 2016a; 2016b; 2016c; 2016d; 2016e; 2017a; $2017 \mathrm{~b} ; 2017 \mathrm{c} ; 2017 \mathrm{~d} ; 2017 \mathrm{e} ; 2017 \mathrm{f} ; 2017 \mathrm{~g} ; 2017 \mathrm{~h}$; $2017 \mathrm{i} ; 2017 \mathrm{j} ; 2017 \mathrm{k} ; 2017 \mathrm{l} ; 2017 \mathrm{~m} ; 2017 \mathrm{n} ; 2017 \mathrm{o}$; $2017 \mathrm{p} ; 2017 \mathrm{q} ; 2017 \mathrm{r} ; 2017 \mathrm{~s} ; 2017 \mathrm{t} ; 2017 \mathrm{u} ; 2017 \mathrm{v}$; $2017 \mathrm{w} ; 2017 \mathrm{x} ; 2017 \mathrm{y} ; 2017 \mathrm{z} ; 2017 \mathrm{aa} ; 2017 \mathrm{ab} ; 2017 \mathrm{ac}$; 2017ad; 2017ae; Petrescu and Calautit, 2016a; 2016b; Reddy et al., 2012; Tabaković et al., 2013; Tang et al., 2013; Tong et al., 2013; Wang et al., 2013; Wen et al., 2012; Antonescu and Petrescu, 1985; 1989; Antonescu et al., 1985a; 1985b; 1986; 1987; 1988; 1994; 1997; 2000a; 2000b; 2001; List the first flights, From Wikipedia; Chen and Patton, 1999; Fernandez et al., 2005; Fonod et al., 2015; Lu et al., 2015; 2016; Murray et al., 2010; Palumbo et al., 2012; Patre and Joshi, 2011; Sevil and Dogan, 2015; Sun and Joshi, 2009; Crickmore, 1997; Donald, 2003; Goodall, 2003; Graham, 2002; Jenkins, 2001; Landis and Dennis, 2005; Clément, Wikipedia; Cayley, Wikipedia; Coandă, Wikipedia; Gunston, 2010; Laming, 2000; Norris, 2010; Goddard, 1916; Kaufman, 1959; Oberth, 1955; Cataldo, 2006; Gruener, 2006; Sherson et al., 2006; Williams, 1995; Venkataraman, 1992; Oppenheimer and Volkoff, 1939; Michell, 1784; Droste, 1915; Finkelstein, 1958; Gorder, 2015; Hewish, 1970).

\section{Materials and Methods}

\section{Dynamic Model with a Degree of Freedom with Double Internal Damping}

In the paper (Wiederrich and Roth, 1974), there is presented a basic single-degree model with two springs and double internal damping to simulate the movement of the cam and punch mechanism (Fig. 1) and the relationships (1-2):

$$
\begin{aligned}
& \ddot{x}+2 \xi_{2} \omega_{2} \dot{x}+\omega_{2}^{2} x=\omega_{1}^{2} y+2 \xi_{1} \omega_{1} \dot{y} \\
& \omega_{1}=\frac{K_{1}}{M} ; \omega_{2}=\frac{\left(K_{1}+K_{2}\right)}{M} ; \\
& 2 \xi_{1} \omega_{1}=\frac{c_{1}}{M} ; 2 \xi_{2} \omega_{2}=\frac{\left(c_{1}+c_{2}\right)}{M}
\end{aligned}
$$




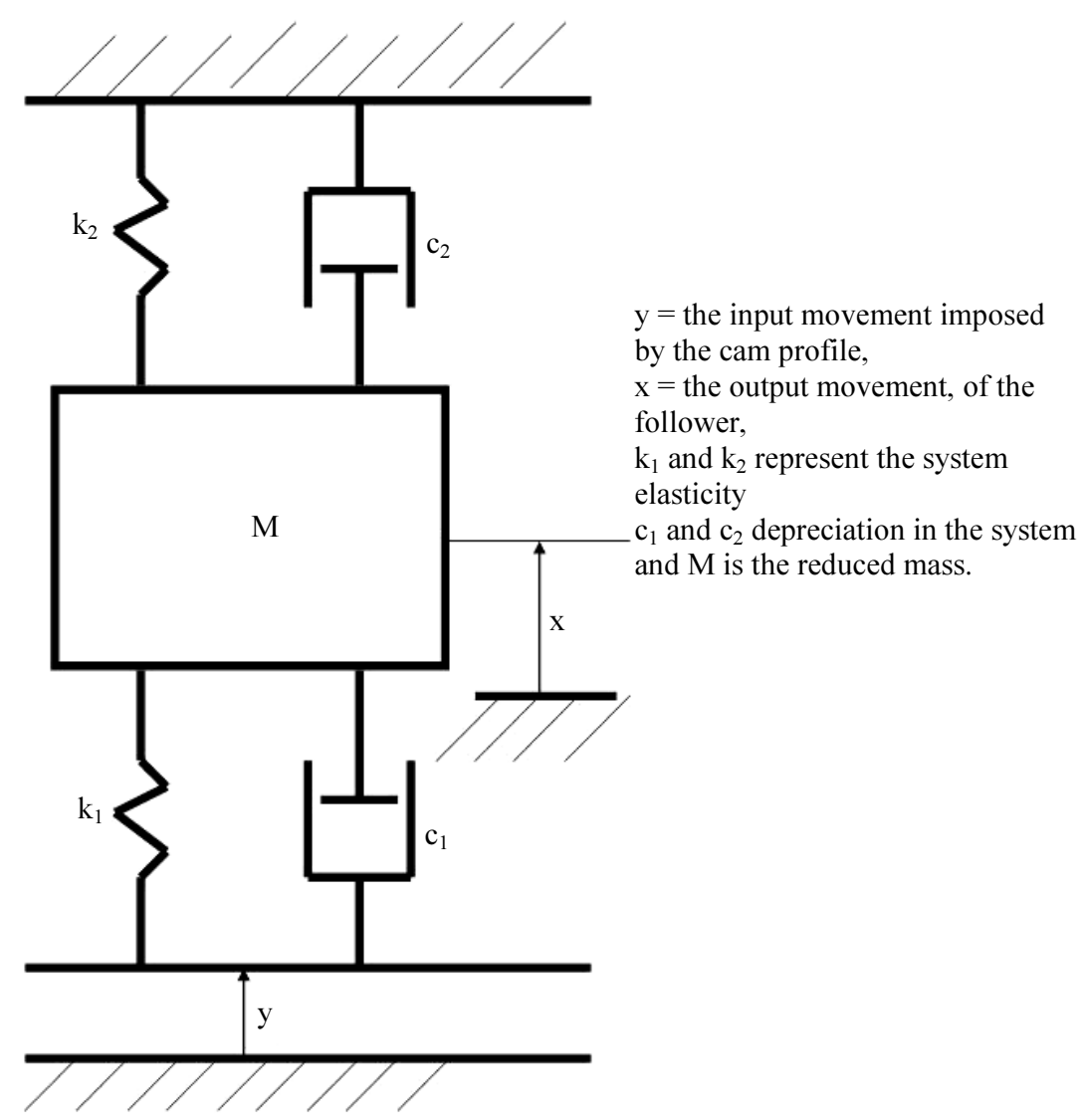

Fig. 1: Dynamic model with a degree of freedom with double internal damping

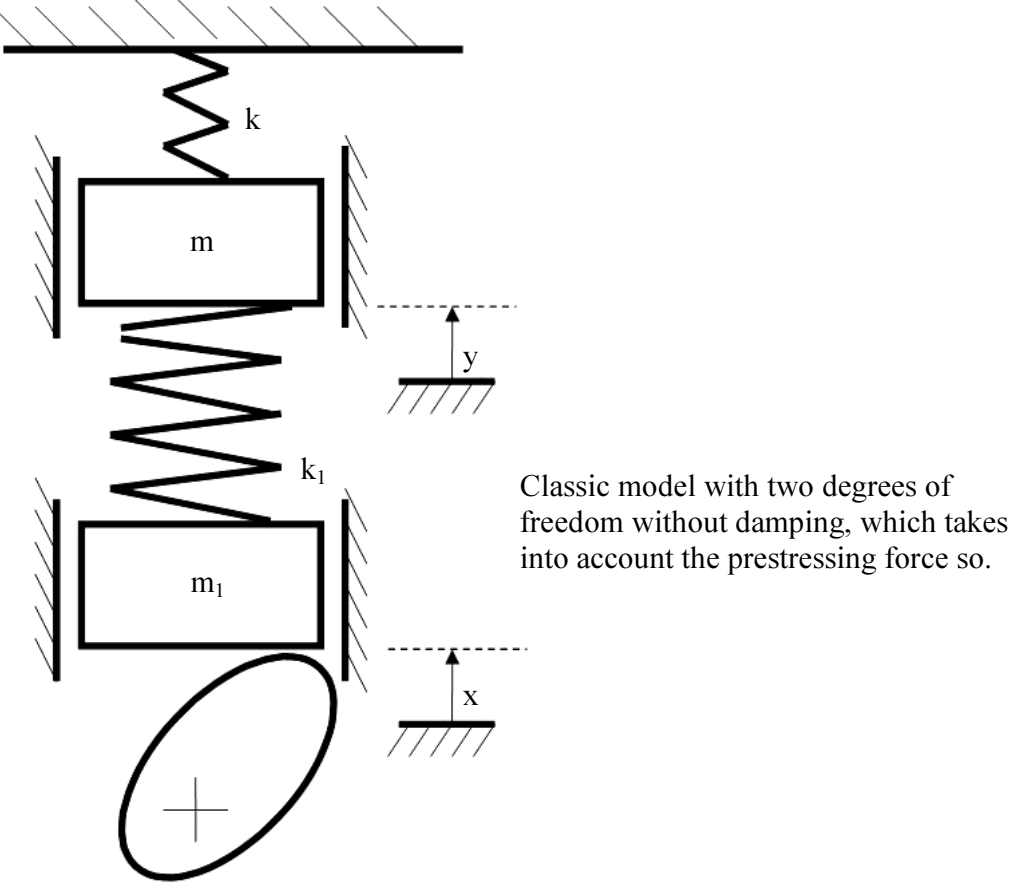

Fig. 2: Dynamic model with two degrees of freedom without internal damping 
The motion equation of the proposed system (1) uses the notations (relations) in the system (2); $\omega_{1}$ and $\omega_{2}$ represents the system's own pulses and is calculated from the relationship system (2), depending on the elasticities $K_{1}$ and $K_{2}$ of the system in Fig. 1 and the reduced mass $\mathrm{M}$ of the system.

\section{Dynamic Model with Two Degrees of Freedom without Internal Damping}

In the paper (Fawcett and Fawcett, 1974), the basic dynamic model of a mechanism with cam, barrel and valve, with two degrees of freedom, without internal damping (Fig. 2, Equation 3-5) is presented:

$y=x+z$

$m \frac{d^{2} y}{d t^{2}}+\left(K_{1}+K\right) y=K_{1} x-s_{0}$

$F_{n}=m_{1} \ddot{x}-K_{1}(y-x)=m_{1} \ddot{x}-k_{1} z$

Dynamic Model with a Degree of Freedom with Internal and External Damping

A dynamic model with both system damping, external (spring valve) and internal damping is the one presented in the paper (Jones and Reeve, 1974), (Fig. 3).

Dynamic Model with a Degree of Freedom, Taking into Account the Internal Damping of the Valve Spring

A dynamic model with a generalized degree of freedom is presented in (Tesar and Matthew, 1974), (Fig. 4).

The motion equation is written as (6):

$\frac{M}{K} \frac{d^{2} y}{d t^{2}}+\frac{C_{r}}{K} \frac{d y}{d t}+\frac{\left(K+K_{r}\right)}{K} y=S$

Using the known relation (7), Equation (6) takes the form (8):

$$
\begin{aligned}
& \frac{d^{K} y}{d t^{K}}=y^{(K)} \omega^{K} \\
& S=\mu_{M} y^{\prime \prime}+\mu_{C} y^{\prime}+\mu_{K} y
\end{aligned}
$$

where the coefficients $\mu$ have the form (9):

$\mu_{M}=\frac{M}{K} \omega^{2} ; \mu_{C}=\frac{C_{r}}{K} \omega ; \mu_{K}=\frac{\left(K+K_{r}\right)}{K} \cong 1, w i t h K_{r}<<K$

The vertical reaction has the form (10):

$$
F_{K}=K(S-y)+P=M \omega^{2} y^{\prime \prime}+C_{r} \omega y^{\prime}+K_{r} y+P
$$

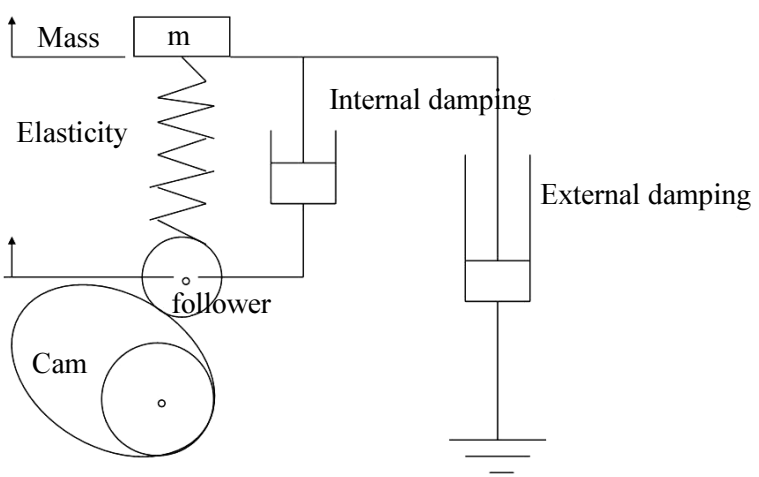

Fig. 3: Dynamic model with a degree of freedom with internal and external damping

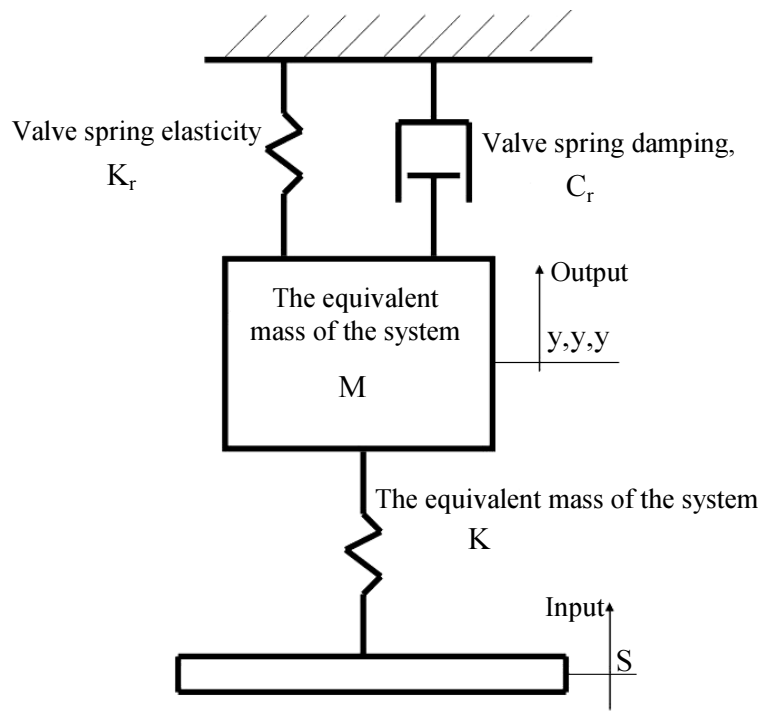

Fig. 4: Dynamic model with a degree of freedom, taking into account the internal damping of the valve spring

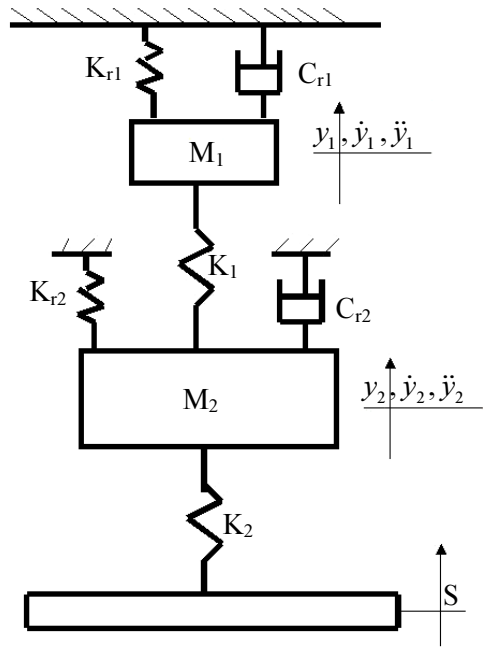

Fig. 5: Dynamic two-degree, dual damping model 


\section{Dynamic Two-Degree, Dual Damping Model}

Also in the paper (Tesar and Matthew, 1974) is presented the model with two degrees of freedom (Fig. 5) with double damping.

The calculation relationships used are (11-16):

$S=P_{4} y_{1}^{\prime \prime \prime}+P_{3} y_{1}^{\prime \prime \prime}+P_{2} y_{1}^{\prime \prime}+P_{1} y_{1}^{\prime}+P_{0} y_{1}$

$P_{4}=\frac{M_{1} M_{2}}{K_{1} K_{2}} \omega^{4}$

$P_{3}=\frac{\left(M_{2} C_{r 1}+M_{1} C_{r 2}\right)}{K_{1} K_{2}} \omega^{3}$

$P_{2}=\frac{\left[M_{2}\left(K_{1}+K_{r 1}\right)+M_{1}\left(K_{1}+K_{2}+K_{r 2}\right)+C_{r 1} C_{r 2}\right]}{K_{1} K_{2}} \omega^{2}$

$P_{1}=\frac{\left[C_{r 2}\left(K_{1}+K_{r 1}\right)+C_{r 1}\left(K_{1}+K_{2}+K_{r 2}\right)\right]}{K_{1} K_{2}} \omega$

$P_{0}=\frac{\left(K_{1} K_{r 1}+K_{1} K_{2}+K_{2} K_{r 1}+K_{1} K_{r 2}+K_{r 1} K_{r 2}\right)}{K_{1} K_{2}}$

Dynamic Model with Four Degrees of Freedom, with Torsional Vibrations

In the paper (Sava, 1970) a dynamic model with 4 degrees of freedom is proposed, obtained as follows: The model has two moving masses; these by vertical vibration each impose a degree of freedom; one mass is thought to vibrate and transverse, generating yet another degree of freedom; and the last degree of freedom is generated by torsional torsion of the camshaft (Fig. 6).

The calculation relationships are (17-20).

The first two equations resolve normal vertical vibrations, the third equation takes into account the camshaft torsional vibration and the last equation (independent of the others), the fourth, deals only with the transverse vibration of the system:

$$
\begin{aligned}
& M \ddot{x}_{1}+2 c \dot{x}_{1}+(k+K) x_{1}-c \dot{x}_{2}-K x_{2}=-P(t) \\
& m \ddot{x}_{2}+2 c \dot{x}_{2}+\left(K+k_{a c}\right) x_{2} \\
& -c \dot{x}_{1}-K x_{1}=F_{v}+c \dot{s}+k_{a c} s \\
& J \ddot{q}+c_{r} \dot{q}+k_{r} q-s^{\prime} k_{a c} x_{2}-c s^{\prime} \dot{x}_{2}= \\
& -s^{\prime}\left(k_{a c} s+c s^{\prime}\right) \\
& m \ddot{u}+k_{t} u=F_{h}
\end{aligned}
$$

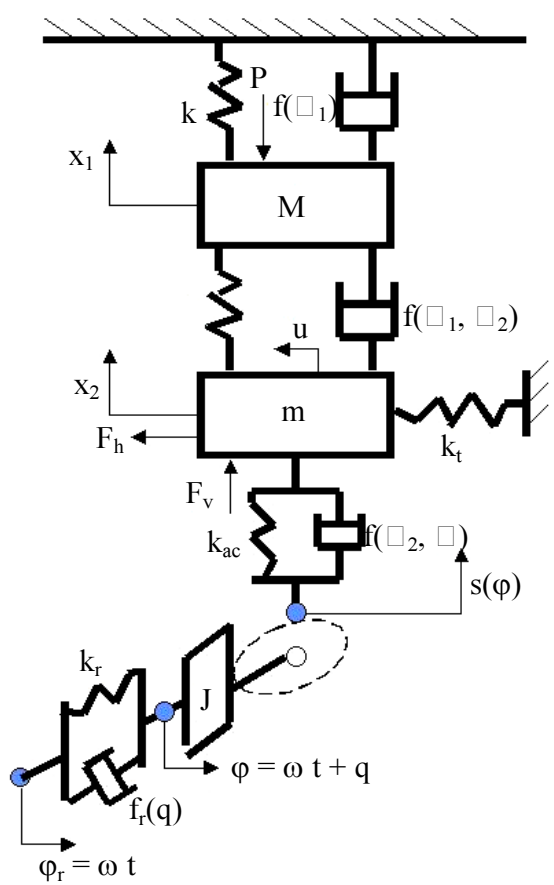

Fig. 6: Dynamic model with four degrees of freedom, with torsional vibrations

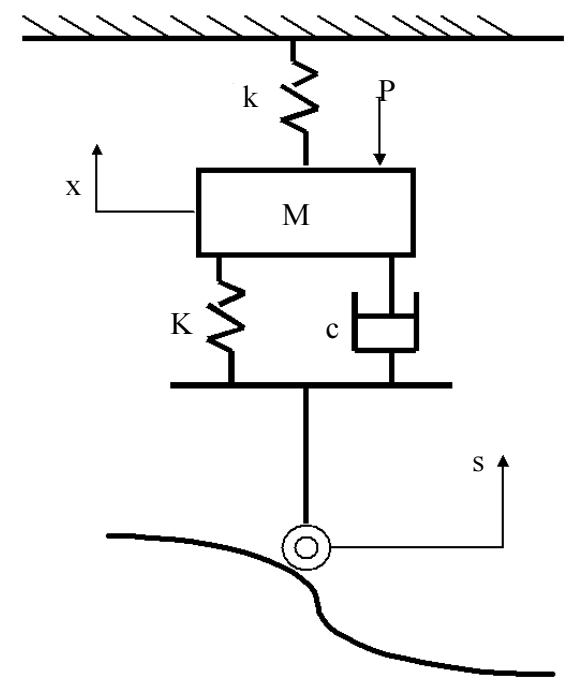

Fig. 7: Mono-dynamic damped dynamic model

\section{Mono-Dynamic Damped Dynamic Model}

Also in the paper (Sava, 1970) is presented a simplified dynamic model, amortized monomass (Fig. 7).

The motion equation used has the form (21):

$M \ddot{x}+c \dot{x}+(k+K) x=c \dot{s}+K s-P$

Which can be written more conveniently, (22): 


$$
x^{\prime \prime}=A_{1}\left(y^{\prime}-x^{\prime}\right)+\omega_{1}^{2}(y-x)-F
$$

Where the coefficients $A_{1}, \omega_{1}^{2}$ and $\mathrm{F}$ are calculated with the expressions given in relation (23):

$$
A_{1}=\frac{c t_{0}}{M} ; \omega_{1}^{2}=\frac{(2 K+k) t_{0}^{2}}{M} ; F=\frac{P t_{0}^{2}}{M s_{0}}
$$

\section{Dynamic Damped Two-Mass Model}

In Fig. 8 the bimass model proposed in the paper (Sava, 1970) is presented.

The mathematical model is written $(24,25)$ :

$$
\begin{aligned}
& M \ddot{x}_{1}+2 c \dot{x}_{1}+(k+K) x_{1}-c \dot{x}_{2}-K x_{2}=-P(t) \\
& m \ddot{x}_{2}+2 c \dot{x}_{2}+\left(K+k_{a c}\right) x_{2}-c \dot{x}_{1}-K x_{1} \\
& =F_{v}+c \dot{s}+k_{a c} s
\end{aligned}
$$

Equations (24-25) can be written as:

$$
\begin{aligned}
& x_{1}^{\prime \prime}=A_{1}\left(x_{2}^{\prime}-2 x_{1}^{\prime}\right)+\omega_{1}^{2}\left(x_{2}-x_{1}\right)-F \\
& x_{2}^{\prime \prime}=A_{1}\left(y^{\prime}-2 x_{2}^{\prime}+x_{1}^{\prime}\right)+\omega_{2}^{2}\left(y-x_{2}\right)+\mu \omega_{1}^{2} x_{1} \\
& +\left[\mu F+(1+\mu) y^{\prime \prime}\right]\left(B_{1}+B_{2} y^{\prime}+B_{3} y\right)
\end{aligned}
$$

where the notations (28) were used. $\mu=\frac{M}{m} \Rightarrow$ the ratio of the two masses, $\omega_{2}^{2}=\frac{\left(k_{a c}+K\right) t_{0}^{2}}{m} \cong \frac{k_{a c} t_{0}^{2}}{m} \Rightarrow$ the self dimensional pulse of the mass $\mathrm{m}$ :

$$
B_{1}=\mu_{1} ; B_{2}=\frac{\mu_{2} s_{0}}{\phi_{0}} ; B_{3}=\mu_{3} s_{0}
$$

\section{A Dynamic Model with a Single Mass with Torsional Vibrations}

In Fig. 9 we can see a dynamic monosomic model that also takes into account the torsional vibrations of the camshaft (Sava, 1970).

The study points out that camshaft torsional vibrations have a negligible influence and can, therefore, be excluded from dynamic calculation models.

The same conclusion results from the work (Sava, 1971) where the torsion model is studied in more detail.

\section{Influence of Transverse Vibrations}

Tappet elasticity, variable length of the camshaft during cam operation, pressure angle variations, camshaft eccentricity, kinetic coupler friction, translation wear, technological and manufacturing errors, system gaming and other factors are factors that favor the presence of a transverse vibration of the rod weight (Sava, 1970).

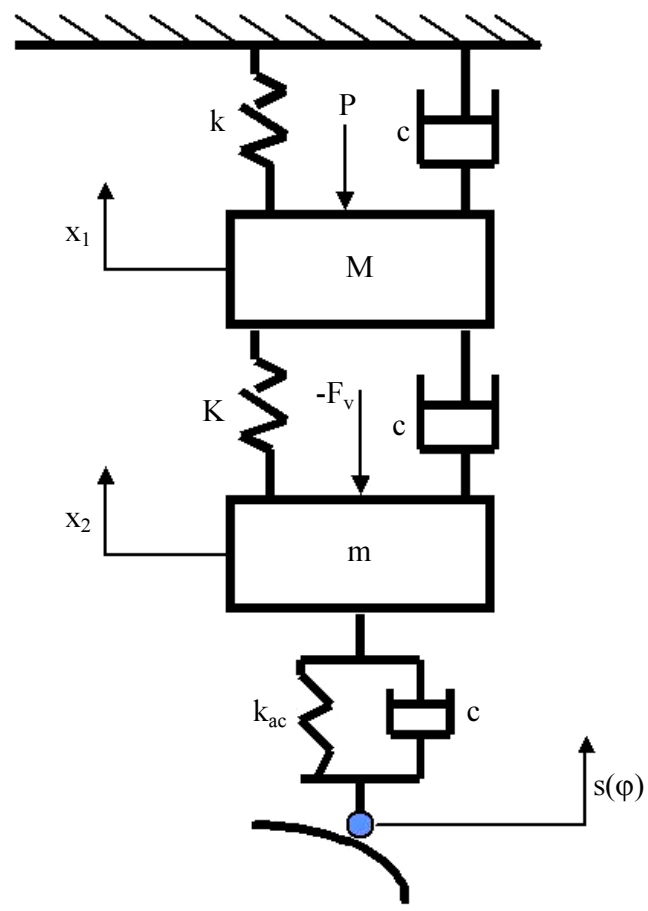

Fig. 8: Dynamic damped two-mass model

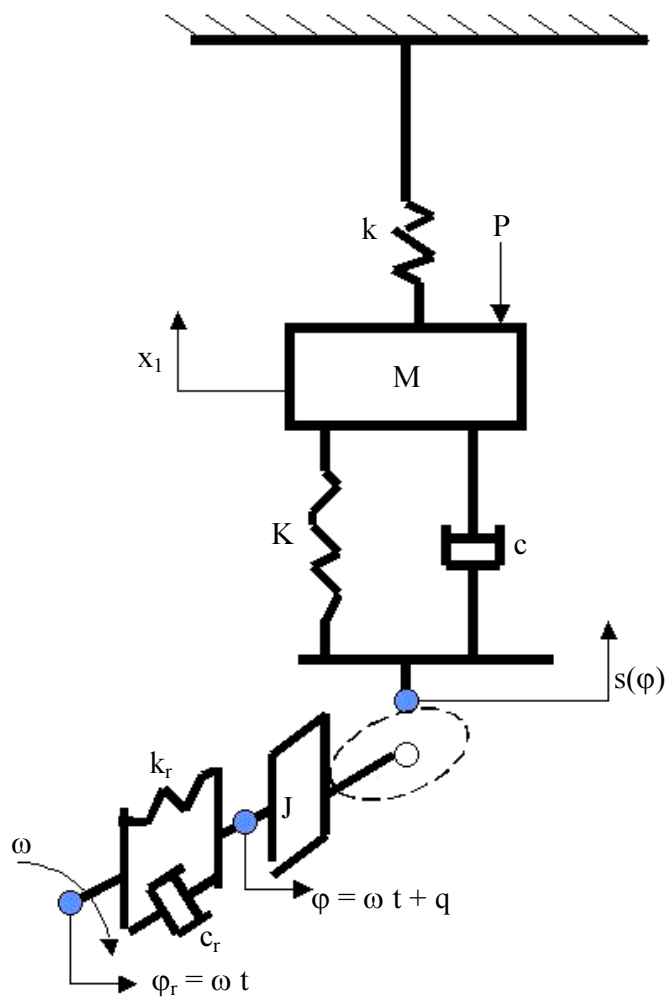

Fig. 9: A dynamic model with a single mass with torsional vibrations 


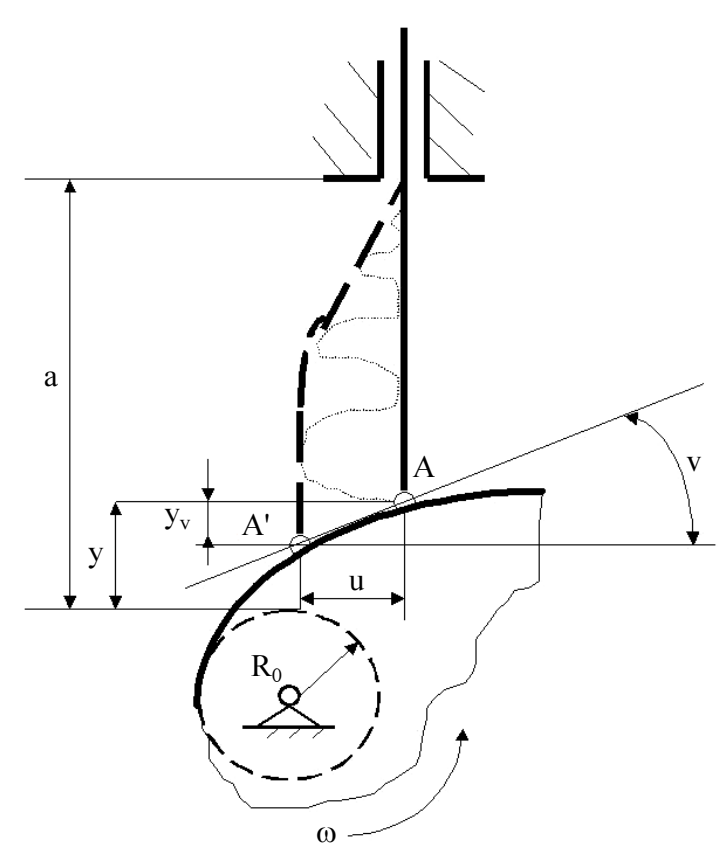

Fig. 10: Influence of transverse vibrations

In the case of high amplitude vibrations, the response parameters to the last element of the tracking system will be influenced. Following Fig. 10, it can be seen that if the curve a is the trajectory of the tip A, the point A will periodically reach point $A^{\prime}$, in which case the actual stroke of the $\mathrm{y}_{\mathrm{r}}$ bar will change according to the law: $y_{r}=$ $y-y_{v}=y$-u.tgv, where $y$ is the longitudinal displacement of the tappet, $u$ represents the transverse displacement of the mass $m$, of the tappet and $v$ is the pressure angle. The actual stroke, $y_{r}$, will change after the law (29):

$$
y_{r}=y-y_{v}=y-\operatorname{utg}(v)
$$

The motion equation (dimensional) is written (30):

$$
u^{\prime \prime}+\frac{A_{1} u}{\left(1-A_{2} y\right)^{3}}=\left[F+(1+\mu) y^{\prime \prime}\right]\left(B_{11}+B_{21} y^{\prime}+B_{31} y\right)
$$

where were denoted by (31) the non-dimensional constants:

$$
\begin{aligned}
& A_{1}=\frac{3 E I t_{0}^{2}}{m a^{3}} ; A_{2}=\frac{s_{0}}{a} ; \\
& B_{11}=f_{1} B_{1} ; B_{21}=f_{1} B_{2} ; B_{31}=f_{1} B_{3}
\end{aligned}
$$

Also in the work (Sava, 1970), the influence of the diameter of the rod, the lifting interval, the maximum length outside the tiller guides, the maximum lifting stroke and the various cam profiles on the A trajectory are analyzed.

Some conclusions:
It is noted that the reduction of the diameter of the rod of the tappet leads to the increase of the amplitude and the decrease of the average frequency of the transverse vibrations. Reducing the diameter of 1.35 times, leads to an increase in amplitude of almost three times and the average frequency decreases sensitively. Initial amplitudes are higher at the beginning of the interval, decreasing to the midpoint of the lifting interval, oscillation becoming insignificant and towards the end of the rise due to the reduction of the length a by decreasing the $\mathrm{y}$ stroke the frequency increases and consequently the amplitude decreases from double to simple the beginning of the interval. Increasing the stick length beyond its 2.2 to $3 \mathrm{~cm}$ guides leads to an increase in vibration amplitude of about 25 times.

The law of motion without leaps in the input acceleration curve reduces the amplitude of the transverse vibration of the tappet. The author of the paper (Sava, 1970) mentions that whatever the influence of the listed parameters is, for the cases considered, the amplitude values remain fairly small and in case of reduced friction in the upper coupler, they can decrease even more. Consequently, the author of the paper (Sava, 1970) concludes that the transverse vibrations of the tachet exist and must draw the attention of the constructor only in the case of exaggerated values of the constants that characterize these vibrations. Regarding the distribution of internal combustion engines, the transverse vibration can be neglected without affecting the response parameters made at the valve.

\section{Results}

\section{Dynamic Model with Four Degrees of Freedom, with Bending Vibrations}

In the paper (Koster, 1974), a four-degree dynamic model with a single oscillating motion mass is presented, representing one of four degrees of freedom. The other three freedoms result from a torsional deformation of the camshaft, a vertical bending (z), camshaft and a bending strain of the same shaft, horizontally (y), all three deformations, in a plane perpendicular to the axis of rotation (Fig. 11). The sum of the momentary efficiency and the momentary losing coefficient is 1 .

The work (Koster, 1974) is extremely interesting by the model it proposes (all types of deformations are being studied), but especially by the hypothesis it advances, namely: The cams speed is not constant but variable, the angular velocity of the cam $\omega=\mathrm{f}(\beta)$ being a function of the position of the cam (the cam angle of rotation $\beta$ ).

The angular velocity of the cam is a function of the position angle $\beta$ (which we usually mark with $\varphi$ ) and its variation is caused by the three deformations (torsion and two bends) of the shaft, as well as by the angular gaps existing between the source motors (drive) and camshaft. 


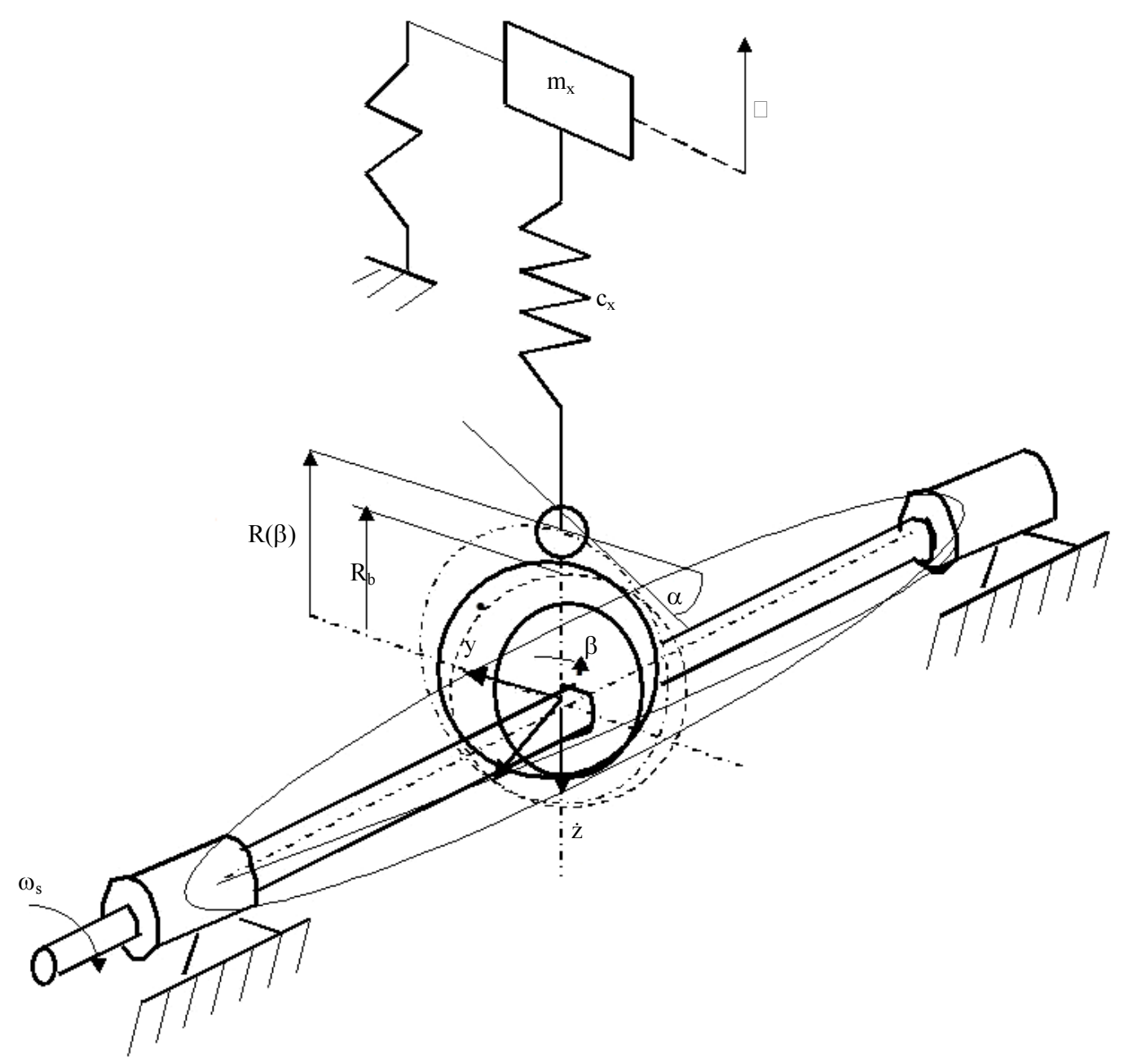

Fig. 11: Dynamic model with four degrees of freedom, with bending vibrations

The mathematical model taking into account the flexibility of the camshaft is the following; the rigidity of the cam between the cam and the cam is a function of the position $\beta$ (cam angle of rotation), see the relationship (32):

$\frac{1}{C(\beta)}=\frac{1}{C_{x}}+\frac{1}{C_{z}}+\left[\frac{1}{C_{\beta}(\beta)}+\frac{1}{C_{y}}\right] \operatorname{tg}^{2} \alpha$

$\frac{1}{C_{c}}=\frac{1}{C_{x}}+\frac{1}{C_{z}}$

where, $1 / C_{c}$ see (33) is a constant rigidity given by the rigidity of the tappet $\left(C_{x}\right)$ and the cam $\left(C_{z}\right)$ in the direction of the tappet:

$\frac{1}{C_{\tan }(\beta)}=\frac{1}{C_{\beta}(\beta)}+\frac{1}{C_{y}}$
And $1 / C_{\tan }(\beta)$ see (34) represents the tangential stiffness, $\mathrm{C}_{\beta}$ being the torsional stiffness of the cam and $C_{y}$ the flexural stiffness at the $\mathrm{y}$ axis of the cam, with $\mathrm{C}_{\beta}(\beta)$ given by the relation (35):

$C_{\beta}(\beta)=\frac{K}{[R(\beta)]^{2}}$

With (33) and (34) the relation (32) is rewritten in the form (36):

$\frac{1}{C(\beta)}=\frac{1}{C_{c}}+\frac{\operatorname{tg}^{2} \alpha}{C_{\tan }(\beta)}$

where, $\alpha$ is the pressure angle, which is generally a function of $\beta$ and at flat tachets (used in distribution mechanisms), it has the constant value (zero): $\alpha=0$.

The motion equation is written as (37): 


$$
m \cdot \ddot{x}+C(\beta) \cdot x=C(\beta) \cdot h(\beta)
$$

where, $h(\beta)$ is the motion law imposed by the cam.

The pressure angle, $\alpha$, thus influences (38):

$\operatorname{tg} \alpha=\frac{1}{R(\beta)} \frac{d h}{d \beta}$

where, $R(\beta)$ is the current radius, which gives the cam position (distance from the center of the cam to the cam contact point) and approximates by the mean radius $R_{1 / 2}$. The relation (38) can be put in the form (39); Where the average radius, $R_{1 / 2}$, is obtained with the formula (40):

$$
\begin{aligned}
& \operatorname{tg} \alpha=\frac{1}{R_{1 / 2}} \frac{\dot{h}}{\omega_{s}} \\
& R_{1 / 2}=R_{b}+\frac{1}{2} h_{m}
\end{aligned}
$$

$R_{b}$ is the radius of the base circle and $h_{m}$ is the maximum projected stroke of the tappet. This produces an average radius, which is used in the calculations for simplifications; $\omega_{s}=$ machine angle, constant, given by machine speed. The Equation (37) can now be written (41):

$$
\ddot{x}=\frac{C_{c} \cdot(h(t)-x)}{m \cdot\left[1+\frac{C_{c}}{C_{\mathrm{tan}}}\left(\frac{1}{R_{\mathrm{l} / 2}} \frac{\dot{h}}{\omega_{s}}\right)^{2}\right]}
$$

The solution of Equation (41) is made for $\alpha=0$, with the following notations.

The period of natural vibration is determined with relation (42):

$$
T_{c}=2 \pi \sqrt{\frac{m}{C_{c}}}
$$

The period of the natural vibration period is obtained by the formula (43):

$$
\tau=\frac{T_{c}}{t_{m}}
$$

The slope during the lifting of the cam (44) is:

$$
\operatorname{tg} \alpha_{m c}=\frac{h_{m}}{R_{1 / 2} \cdot \beta_{m}}
$$

The shaft stiffness factor is obtained by the formula (45):

$$
F_{a}=\frac{C_{c}}{C_{\tan }} \operatorname{tg}^{2} \alpha_{m c}
$$

With dimensional parameters given by (46):

$$
H=\frac{h}{h_{m}} ; X=\frac{x}{h_{m}} ; T=\frac{t}{t_{m}} ; \dot{H}=\frac{h}{h_{m}} t_{m} ; \ddot{X}=\frac{x}{h_{m}} t_{m}^{2}
$$

The motion equation is written in the form (47):

$\ddot{X}=\left(\frac{2 \pi}{\tau}\right)^{2} \cdot \frac{H-X}{1+\dot{H}^{2} \cdot F_{a}}$

The nominal curve of the cam is known (48) and (49):

$$
\begin{aligned}
& \dot{H}=\dot{H}(T) \\
& H=H(T)
\end{aligned}
$$

With (47), (48) and (49) the dynamic response is calculated by a numerical method.

The author of the paper (Koster, 1974) gives a numerical example for a motion law, corresponding to the cycloid cam (50):

$$
H=T-\frac{1}{2 \pi} \sin (2 \pi \cdot T)
$$

The work is especially interesting in how it manages to transform the four degrees of freedom into one, ultimately using a single equation of motion along the main axis. The dynamic model presented can be used wholly or only partially, so that on another classical or new dynamic model, the idea of using deformations on different axes with their cumulative effect on a single axis is inserted.

\section{Discussion}

The development and diversification of road vehicles and vehicles, especially of cars, together with thermal engines, especially internal combustion engines (being more compact, robust, more independent, more reliable, stronger, more dynamic etc.)., has also forced the development of devices, mechanisms and component assemblies at an alert pace. The most studied are power and transmission trains.

The four-stroke internal combustion engine (fourstroke, Otto or Diesel) comprises in most cases (with the exception of rotary motors) and one or more camshafts, valves, valves and so on.

The classical distribution mechanisms are robust, reliable, dynamic, fast-response and although they 
functioned with very low mechanical efficiency, taking much of the engine power and effectively causing additional pollution and increased fuel consumption, they could not be abandoned until the present. Another problem was the low speed from which these mechanisms begin to produce vibrations and very high noises.

Regarding the situation realistically, the mechanisms of cam casting and sticking are those that could have produced more industrial, economic, social revolutions in the development of mankind. They have contributed substantially to the development of internal combustion engines and their spreading to the detriment of external combustion (Steam or Stirling) combustion engines.

The problem of very low yields, high emissions and very high power and fuel consumption has been greatly improved and regulated over the past 20-30 years by developing and introducing modern distribution mechanisms that, besides higher yields immediately deliver a high fuel economy) also performs optimal noise-free, vibration-free, no-smoky operation, as the maximum possible engine speed has increased from 6000 to 30000 [rpm].

The paper tries to provide additional support to the development of distribution mechanisms so that their performance and the engines they will be able to further enhance.

Particular performance is the further increase in the mechanical efficiency of distribution systems, up to unprecedented quotas so far, which will bring a major fuel economy.

The current oil and energy reserves of mankind are limited. Until the implementation of new energy sources (to take real control over fossil fuels), a real alternative source of energy and fuel is even "the reduction in fuel consumption of a motor vehicle", whether we burn oil, gas and petroleum derivatives, whether we will implement biofuels first and later hydrogen (extracted from water).

The drop in fuel consumption for a given vehicle type over a hundred kilometers traveled has been consistently since 1980 and has continued to continue in the future.

Even if hybrids and electric motor cars are to be multiplied, let us not forget that they have to be charged with electricity, which is generally obtained by burning fossil fuels, especially oil and gas, in a current planetary proportion of about $60 \%$. We burn oil in large heat plants to warm up, have domestic hot water and electricity to consume and some of that energy is extra and we add it to electric cars (electric vehicles), but the global energy problem is not resolved, the crisis even deepens. This was the case when we electrified the railroad for trains, when we generalized trams, trolleybuses and subways, consuming more electric power produced mainly from oil; oil consumption has grown a lot, its price has had a huge leap and we look at how the reserves disappear quickly.
Generally generalizing electric cars (though we are not really ready for this), we will give a new blow to oil and gas reserves.

Fortunately, biofuels, biomass and nuclear power have developed very much lately (currently based on the nuclear fission reaction). These together with the hydroelectric power plants have managed to produce about $40 \%$ of the total energy consumed globally. Only about $2-3 \%$ of global energy resources are produced by various other alternative methods (despite the efforts made so far).

This should not disarm us and abandon the implementation of solar, wind, etc.

However, as a first necessity to further reduce the share of global energy from oil and gas, the first vigorous measures that will need to be pursued will be to increase biomass and biofuels production along with the widening of the number of nuclear power plants (despite some undesirable events, which only show that nuclear fission power plants must be built with a high degree of safety and in no way eliminated from now on and they are still the one that has been so far "a bad evil").

Alternative sources will take them on an unprecedented scale, but we expect the energy they provide to be more consistent in global percentages so that we can rely on them in a real way (otherwise, we risk that all these alternative energies remain a sort of "fairy tale").

Hydrogen fuel energy "when it starts when it stops" so there is no real time now to save energy through them, so they can no longer be priority, but the trucks and buses could even be implemented now that the storage problems have been partially solved. The bigger problem with hydrogen is no longer the safe storage, but the high amount of energy needed to extract it and especially for its bottling. The huge amount of electricity consumed for bottling hydrogen will have to be obtained entirely through alternative energy sources, otherwise hydrogen programs will not be profitable for humanity at least for the time being. Personally, I think the immediate use of hydrogen extracted from the water with alternative energies would be more appropriate for seagoing vessels.

Maybe just to say that due to his energy crisis (and not just energy, from 1970 until today), the production of cars and cars has increased at an alert pace (but naturally) instead of falling and they have and were marketed and used. The world's energy crisis (in the 1970s) began to rise from around 200 million vehicles worldwide, to about 350 million in 1980 (when the world's energy and global fuel crisis was declared), about 500 million vehicles worldwide and in 1997 the number of world-registered vehicles exceeded 600 million.

Also in the work (Sava, 1970), the influence of the diameter of the rod, the lifting interval, the maximum length outside the tiller guides, the maximum lifting stroke and the various cam profiles on the A trajectory are analyzed.

It is noted that the reduction of the diameter of the rod of the tappet leads to the increase of the amplitude 
and the decrease of the average frequency of the transverse vibrations. Reducing the diameter of 1.35 times, leads to an increase in amplitude of almost three times and the average frequency decreases sensitively. Initial amplitudes are higher at the beginning of the interval, decreasing to the midpoint of the lifting interval, oscillation becoming insignificant and towards the end of the rise due to the reduction of the length a by decreasing the $y$ stroke the frequency increases and consequently the amplitude decreases from double to simple the beginning of the interval. Increasing the stick length beyond its 2.2 to $3 \mathrm{~cm}$ guides leads to an increase in vibration amplitude of about 25 times.

\section{Conclusions}

Rigid memory mechanisms have played an important role in the history of mankind, contributing greatly to the industrial, economic, social changes in society, thus leading to a real evolution of mankind.

Used in automated tissue wars, in cars as distribution mechanisms, automated machines, mechanical transmissions, robots and mechatronics, precision devices and medical devices, these mechanisms have been real support for mankind along the time.

For this reason, one considered useful this paper, which presents some dynamic models that played an essential role in designing rigid memory mechanisms.

\section{Acknowledgement}

This text was acknowledged and appreciated by Dr. Veturia CHIROIU Honorific member of Technical Sciences Academy of Romania (ASTR) PhD supervisor in Mechanical Engineering.

\section{Funding Information}

Research contract: Contract number 36-5-4D/1986 from 24IV1985, beneficiary CNST RO (Romanian National Center for Science and Technology) Improving dynamic mechanisms internal combustion engines. All these matters are copyrighted. Copyrights: 548-cgiywDssin, from: 22-04-2010, 08:48:48.

\section{Ethics}

This article is original and contains unpublished material. Authors declare that are not ethical issues and no conflict of interest that may arise after the publication of this manuscript.

\section{References}

Antonescu, P., 2000. Mechanisms and Handlers. 1st Edn., Printech Publishing House. Bucharest.
Antonescu, P. and F. Petrescu, 1985. Analytical method of synthesis of cam mechanism and flat stick. Proceedings of the 4th International Symposium on Mechanism Theory and Practice, (TPM' 85), Bucharest.

Antonescu, P. and F. Petrescu, 1989. Contributions to cinetoelastodynamic analysis of distribution mechanisms. Bucharest.

Antonescu, P., M. Oprean and F. Petrescu, 1985a. Contributions to the synthesis of oscillating cam mechanism and oscillating flat stick. Proceedings of the 4th International Symposium on Theory and Practice of Mechanisms, (TPM' 85), Bucharest.

Antonescu, P., M. Oprean and F. Petrescu, 1985b. At the projection of the oscillante cams, there are mechanisms and distribution variables. Proceedings of the 5th Conference for Engines, Automobiles, Tractors and Agricultural Machines, I-Engines and Automobiles, (AMA' 85), Brasov.

Antonescu, P., M. Oprean and F. Petrescu, 1986. Projection of the profile of the rotating camshaft acting on the oscillating plate with disengagement. Proceedings of the 3rd National Computer Assisted Designing Symposium in Mechanisms and Machine Bodies, (MOM' 86), Brasov.

Antonescu, P., M. Oprean and F. Petrescu, 1987. Dynamic analysis of the cam distribution mechanisms. Proceedings of the Seventh National Symposium of Industrial Robots and Spatial Mechanisms, (IMS' 87), Bucharest,

Antonescu, P., M. Oprean and F. Petrescu, 1988. Analytical synthesis of Kurz profile, rotating flat cam cam. Machine Build. Rev. Bucharest.

Antonescu, P., F. Petrescu and O. Antonescu, 1994. Contributions to the synthesis of the rotating cam mechanism and the tip of the balancing tip. Brasov.

Antonescu, P., F. Petrescu and D. Antonescu, 1997. Geometrical synthesis of the rotary cam and balance tappet mechanism. Bucharest.

Antonescu, P., F. Petrescu and O. Antonescu, 2000a. Contributions to the synthesis of the rotary disc-cam profile. Proceedings of the 8th International Conference on Theory of Machines and Mechanisms, (TMM' 00), Liberec, Czech Republic, pp: 51-56.

Antonescu, P., F. Petrescu and O. Antonescu, 2000b. Synthesis of the rotary cam profile with balance follower. Proceedings of the 8th Symposium on Mechanisms and Mechanical Transmissions, (MMT'000), Timişoara, pp: 39-44.

Antonescu, P., F. Petrescu and O. Antonescu, 2001. Contributions to the synthesis of mechanisms with rotary disc-cam. Proceedings of the 8th IFToMM International Symposium on Theory of Machines and Mechanisms, (TMM' 01), Bucharest, ROMANIA, pp: 31-36. 
Aversa, R., R.V. Petrescu, A. Apicella and F.I.T. Petrescu, 2017a. Nano-diamond hybrid materials for structural biomedical application. Am. J. Biochem. Biotechnol., 13: 34-41. DOI: 10.3844/ajbbsp.2017.34.41

Aversa, R., R.V. Petrescu, B. Akash, R.B. Bucinell and J.M. Corchado et al., 2017b. Kinematics and forces to a new model forging manipulator. Am. J. Applied Sci., 14: 60-80. DOI: 10.3844/ajassp.2017.60.80

Aversa, R., R.V. Petrescu, A. Apicella, F.I.T. Petrescu and J.K. Calautit et al., 2017c. Something about the V engines design. Am. J. Applied Sci., 14: 34-52. DOI: 10.3844/ajassp.2017.34.52

Aversa, R., D. Parcesepe, R.V. Petrescu, F. Berto and G. Chen et al., 2017d. Processability of bulk metallic glasses. Am. J. Applied Sci., 14: 294301. DOI: 10.3844/ajassp.2017.294.301

Aversa, R., R.V. Petrescu, A. Apicella and F.I.T. Petrescu, 2017e. Modern transportation and photovoltaic energy for urban ecotourism. Transylvanian Rev. Administrative Sci., 13: 5-20. DOI: $10.24193 /$ tras.SI2017.1

Aversa, R., F.I.T. Petrescu, R.V. Petrescu and A. Apicella, 2016a. Biomimetic FEA bone modeling for customized hybrid biological prostheses development. Am. J. Applied Sci., 13: 1060-1067. DOI: 10.3844/ajassp.2016.1060.1067

Aversa, R., D. Parcesepe, R.V. Petrescu, G. Chen and F.I.T. Petrescu et al., 2016b. Glassy amorphous metal injection molded induced morphological defects. Am. J. Applied Sci., 13: 1476-1482.

DOI: $10.3844 /$ ajassp.2016.1476.1482

Aversa, R., R.V. Petrescu, F.I.T. Petrescu and A. Apicella, 2016c. Smart-factory: Optimization and process control of composite centrifuged pipes. Am. J. Applied Sci., 13: 1330-1341. DOI: 10.3844/ajassp.2016.1330.1341

Aversa, R., F. Tamburrino, R.V. Petrescu, F.I.T. Petrescu and M. Artur et al., 2016d. Biomechanically inspired shape memory effect machines driven by muscle like acting NiTi alloys. Am. J. Applied Sci., 13: 1264-1271. DOI: 10.3844/ajassp.2016.1264.1271

Cao, W., H. Ding, Z. Bin and C. Ziming, 2013. New structural representation and digital-analysis platform for symmetrical parallel mechanisms. Int. J. Adv. Robot. Sys. DOI: 10.5772/56380

Cataldo, R., 2006 Overview of planetary power system options for education. ITEA Human Exploration Project Authors, 2006, at Glenn Research Center. Brooke Park, OH.

Cayley George, From Wikipedia. The free encyclopedia. https://en.wikipedia.org/wiki/George_Cayley

Chen, J. and R.J. Patton, 1999. Robust Model-Based Fault Diagnosis for Dynamic Systems. 1st Edn., Kluwer Academic Publisher, Boston, ISBN-10: 0792384113, pp: 356.
Clément, A., From Wikipedia. The free encyclopedia. https://en.wikipedia.org/wiki/Cl\%C3\%A9ment_Ader

Coandă-1910, From Wikipedia. The free encyclopedia. https://en.wikipedia.org/wiki/Coand\%C4\%83-1910

Comănescu, A., D. Comănescu, I. Dugăeşescu and A. Boureci, 2010. The Basics of Modeling Mechanisms. 1st Edn., Politehnica Press Publishing House, Bucharest, ISBN-10: 978-606-515-115-4, pp: 274.

Crickmore, P.F., 1997. Lockheed's blackbirds-A-12, YF-12 and SR-71A. Wings Fame, 8: 30-93.

Donald, D., 2003. Lockheed's blackbirds: A-12, YF-12 and SR-71". Black Jets. AIRtime.

Dong, H., N. Giakoumidis, N. Figueroa and N. Mavridis, 2013. Approaching behaviour monitor and vibration indication in developing a General Moving Object Alarm System (GMOAS). Int. J. Adv. Robot. Sys. DOI: $10.5772 / 56586$

Droste, J., 1915. On the field of a single centre in Einstein's theory of gravitation. Koninklijke Nederlandsche Akademie van Wetenschappen Proc., 17: 998-1011.

De Melo, L.F., S.F. Rosário and J.M., Rosário, 2012. Mobile robot navigation modelling, control and applications. Int. Rev. Modell. Simulat., 5: 1059-1068.

Fawcett, G.F. and J.N. Fawcett, 1974. Comparison of Polydyne and Non Polydyne Cams. In: Cams and Cam Mechanisms, Rees Joned, J. (Ed.), MEP, London and Birmingham, Alabama.

Fernandez, V., F. Luis, L.F. Penin, J. Araujo and A. Caramagno, 2005. Modeling and FDI specification of a RLV Re-entry for robust estimation of sensor and actuator faults. Proceedings of the AIAA Guidance, Navigation and Control Conference and Exhibit, Aug. 15-18, San Francisco.

DOI: $10.2514 / 6.2005-6254$

Finkelstein, D., 1958. Past-future asymmetry of the gravitational field of a point particle. Physical Rev., 110: 965-967.

Fonod, R., D. Henry, C. Charbonnel and E. Bornschlegl et al., 2015. Position and attitude model-based thruster fault diagnosis: A comparison study. J. Guidance Control Dynam., 38: 1012-1026. DOI: $10.2514 / 1 . G 000309$

Frățilă, G., M. Frățilă and S. Samoilă, 2011. Automobiles, Construction, Exploitation, Reparation. 10th Edn., EDP, Bucharest, ISBN-13: 978-973-30-2857-4.

Garcia, E., M.A. Jimenez, P.G. De Santos and M. Armada, 2007. The evolution of robotics research. IEEE Robot. Autom. Magaz., 14: 90-103. DOI: 10.1109/MRA.2007.339608

Garcia-Murillo, M., J. Gallardo-Alvarado and E. Castillo-Castaneda, 2013. Finding the generalized forces of a series-parallel manipulator. IJARS. DOI: $10.5772 / 53824$ 
Goddard, 1916. Rocket apparatus patent December 15, 1916, Smithsonian Institution Archives.

Goodall, J., 2003. Lockheed's SR-71 "Blackbird" Family. 1st Edn., Aerofax/Midland Publishing, Hinckley, UK, ISBN-10: 1-85780-138-5.

Gorder, P.F., 2015. What's on the surface of a black hole? Not a "firewall" - and the nature of the universe depends on it, a physicist explains.

Graham, R.H., 2002. SR-71 Blackbird: Stories, Tales and Legends. 1st Edn., Zenith Imprint, North Branch, Minnesota, ISBN-10: 1610607503.

Gruener, J.E., 2006. Lunar exploration (Presentation to ITEA Human Exploration Project Authors, Johnson Space Center). Houston, TX.

Gunston, B., 2010. Airbus: The Complete Story. 1st Edn., Haynes Publishing UK, Sparkford, ISBN-10: 1844255859, pp: 288.

He, B., Z. Wang, Q. Li, H. Xie and R. Shen, 2013. An analytic method for the kinematics and dynamics of a multiple-backbone continuum robot. IJARS. DOI: $10.5772 / 54051$

Hewish, A., 1970. Pulsars. Ann. Rev. Astronomy Astrophys., 8: 265-296.

Jenkins, D.R., 2001. Lockheed Secret Projects: Inside the Skunk Works. 1st Edn., Zenith Imprint, St. Paul, Minnesota: MBI Publishing Company, ISBN-10: 1610607287.

Jones, J.R. and J.E. Reeve, 1974. Dynamic Response of Cam Curves Based on Sinusoidal Segments. In: Cams and Cam Mechanisms, Rees Jones, J. (Ed.), London and Birmingham, Alabama.

Kaufman, H.R., 1959 Installations at NASA Glenn.

Koster, M.P., 1974. The Effects of Backlash and Shaft Flexibility on the Dynamic Behavior of a Cam Mechanism. In: Cams and Cam Mechanisms, Rees Jones, J. (Ed.), London and Birmingham, Alabama, pp: 141-146.

Laming, T., 2000. Airbus A320. 1st Edn., Zenith Press.

Landis, T.R. and D.R. Jenkins, 2005. Lockheed Blackbirds. 1st Edn., Specialty Press, North Branch, ISBN-10: 1580070868, pp: 104.

Lee, B.J., 2013. Geometrical derivation of differential kinematics to calibrate model parameters of flexible manipulator. Int. J. Adv. Robot. Sys. DOI: $10.5772 / 55592$

Lin, W., B. Li, X. Yang and D. Zhang, 2013. Modelling and control of inverse dynamics for a 5-DOF parallel kinematic polishing machine. Int. J. Adv. Robot. Sys. DOI: 10.5772/54966

List the first flights, From Wikipedia, free encyclopedia. https://ro.wikipedia.org/wiki/List $\% C 4 \% 83$ cu_prim ele zboruri

Liu, H., W. Zhou, X. Lai and S. Zhu, 2013. An efficient inverse kinematic algorithm for a PUMA560structured robot manipulator. IJARS.

DOI: $10.5772 / 56403$
Lu, P., L. Van Eykeren, E. van Kampen and Q. P. Chu, 2015. Selective-reinitialization multiple-model adaptive estimation for fault detection and diagnosis. J. Guidance Control Dynam., 38: 1409-1424. DOI: 10.2514/1.G000587

Lu, P., L. Van Eykeren, E. van Kampen, C.C. de Visser and Q.P. Chu, 2016. Adaptive three-step kalman filter for air data sensor fault detection and diagnosis. J. Guidance Control Dynam., 39: 590-604. DOI: $10.2514 / 1 . G 001313$

Michell, J., 1784. On the means of discovering the distance, magnitude and c. of the fixed stars, in consequence of the diminution of the velocity of their light, in case such a diminution should be found to take place in any of them and such other data should be procured from observations, as would be farther necessary for that purpose. Philosophical Trans. Royal Society, 74: 35-57.

Mirsayar, M.M., V.A. Joneidi, R.V. Petrescu, F.I.T. Petrescu and F. Berto, 2017. Extended MTSN criterion for fracture analysis of soda lime glass. Eng. Fracture Mechan., 178: 50-59.

DOI: 10.1016/j.engfracmech.2017.04.018

Murray, K., A. Marcos and L.F. Penin, 2010. Development and testing of a GNC-FDI filter for a reusable launch vehicle during ascent. Proceedings of the AIAA Guidance, Navigation and Control Conference, Aug. 2-5, Toronto, Ontario Canada. DOI: $10.2514 / 6.2010-8195$

Norris, G., 2010. Airbus A380: Superjumbo of the 21st Century. 1st Edn., Zenith Press.

Oberth, H., 1955. They come from outer space. Flying Saucer Rev., 1: 12-14.

Oppenheimer, J.R. and G.M. Volkoff, 1939. On massive neutron cores. Physical Rev., 55: 374-381.

Padula, F. and V. Perdereau, 2013. An on-line path planner for industrial manipulators. Int. J. Adv. Robot. Syst. DOI: 10.5772/55063

Palumbo, R., G. Morani, M. De Stefano Fumo, C. Richiello and M. Di Donato et al., 2012. Concept study of an atmospheric reentry using a winged unmanned space vehicle. Proceedings of the 18th AIAA/3AF International Space Planes and Hypersonic Systems and Technologies Conference, Sept. 24-28, Tours, France. DOI: 10.2514/6.2012-5857

Patre, P. and S.M. Joshi, 2011. Accommodating sensor bias in MRAC for state tracking. Proceedings of the AIAA Guidance, Navigation and Control Conference, Aug. 8-11, Portland, Oregon. DOI: $10.2514 / 6.2011-6605$

Pelecudi, C., 1967. The Basics of Mechanism Analysis. Publishing house: Academy of the People's Republic of Romania. 
Perumaal, S. and N. Jawahar, 2013. Automated trajectory planner of industrial robot for pick-andplace task. IJARS. DOI: 10.5772/53940

Petrescu, F. and R. Petrescu, 1995a. Contributions to optimization of the polynomial motion laws of the stick from the internal combustion engine distribution mechanism. Bucharest.

Petrescu, F. and R. Petrescu, 1995b. Contributions to the synthesis of internal combustion engine distribution mechanisms. Bucharest.

Petrescu, F. and R. Petrescu, 1997a. Dynamics of cam mechanisms (exemplified on the classic distribution mechanism). Bucharest.

Petrescu, F. and R. Petrescu, 1997b. Contributions to the synthesis of the distribution mechanisms of internal combustion engines with Cartesian coordinate method. Bucharest.

Petrescu, F. and R. Petrescu, 1997c. Contributions to maximizing polynomial laws for the active stroke of the distribution mechanism from internal combustion engines. Bucharest.

Petrescu, F. and R. Petrescu, 2000a. Synthesis of distribution mechanisms by the rectangular (cartesian) coordinate method. University of Craiova, Craiova.

Petrescu, F. and R. Petrescu, 2000b. The design (synthesis) of cams using the polar coordinate method (the triangle method). University of Craiova, Craiova.

Petrescu, F. and R. Petrescu, 2002a. Motion laws for cams. Proceedings of the 7th National Symposium with International Participation Computer Assisted Design, (PAC' 02), Braşov, pp: 321-326.

Petrescu, F. and R. Petrescu, 2002b. Camshaft dynamics elements. Proceedings of the 7th National Symposium with International Participation Computer Assisted Design, (PAC' 02), Braşov, pp: 327-332.

Petrescu, F. and R. Petrescu, 2003. Some elements regarding the improvement of the engine design. Proceedings of the 8th National Symposium, Descriptive Geometry, Technical Graphics and Design, (GTD’ 03), Braşov, pp: 353-358.

Petrescu, F. and R. Petrescu, 2005a. The cam design for a better efficiency. Proceedings of the International Conference on Engineering Graphics and Design, (EGD' 05), Bucharest, pp: 245-248.

Petrescu, F. and R. Petrescu, 2005b. Contributions at the dynamics of cams. Proceedings of the 9th IFToMM International Symposium on Theory of Machines and Mechanisms, (TMM' 05), Bucharest, Romania, pp: 123-128.

Petrescu, F. and R. Petrescu, 2005c. Determining the dynamic efficiency of cams. Proceedings of the 9th IFToMM International Symposium on Theory of Machines and Mechanisms, (TMM' 05), Bucharest, Romania, pp: 129-134.
Petrescu, F. and R. Petrescu, 2005d. An original internal combustion engine. Proceedings of the 9th IFToMM International Symposium on Theory of Machines and Mechanisms, (TMM' 05), Bucharest, Romania, pp: 135-140.

Petrescu, F. and R. Petrescu, 2005e. Determining the mechanical efficiency of Otto engine's mechanism. Proceedings of the 9th IFToMM International Symposium on Theory of Machines and Mechanisms, (TMM' 05), Bucharest, Romania, pp: 141-146.

Petrescu, F.I. and R.V. Petrescu, 2013. Cinematics of the 3R Dyad. Engevista, 15: 118-124.

Petrescu, F.I.T. and R.V. Petrescu, 2012a. The Aviation History. 1st Edn., Books On Demand, ISBN-13: 978-3848230778.

Petrescu, F.I. and R.V. Petrescu, 2012b. MecatronicaSisteme Seriale si Paralele. 1st Edn., Create Space Publisher, USA, ISBN-10: 978-1-4750-6613-5, pp: 128.

Petrescu, F.I. and R.V. Petrescu, 2011. Mechanical Systems, Serial and Parallel-Course (in Romanian). 1st Edn., LULU Publisher, London, UK, ISBN-10: 978-1-4466-0039-9, pp: 124.

Petrescu, F.I. and R.V. Petrescu, 2016a. Parallel moving mechanical systems kinematics. ENGEVISTA, 18: 455-491.

Petrescu, F.I. and R.V. Petrescu, 2016b. Direct and inverse kinematics to the anthropomorphic robots, ENGEVISTA, 18: 109-124.

Petrescu, F. and R. Petrescu, 2016c. An Otto engine dynamic model. IJM\&P, 7: 038-048.

Petrescu, F.I. and R.V. Petrescu, 2016d. Otto motor dynamics, GEINTEC, 6: 3392-3406.

Petrescu, F.I. and R.V. Petrescu, 2016e. Dynamic cinematic to a structure 2R. GEINTEC, 6: 3143-3154.

Petrescu, F.I., B. Grecu, A. Comanescu and R.V. Petrescu, 2009. Some mechanical design elements. Proceeding of the International Conference on Computational Mechanics and Virtual Engineering, (MEC' 09), Braşov, pp: 520-525.

Petrescu, R.V., R. Aversa, A. Apicella, M.M. Mirsayar and F.I.T. Petrescu, 2016a. About the gear efficiency to a simple planetary train. Am. J. Applied Sci., 13: 1428-1436. DOI: 10.3844/ajassp.2016.1428.1436

Petrescu, R.V., R. Aversa, A. Apicella, S. Li and G. Chen et al., 2016b. Something about electron dimension. Am. J. Applied Sci., 13: 1272-1276. DOI: 10.3844 /ajassp.2016.1272.1276

Petrescu, F.I.T., A. Apicella, R. Aversa, R.V. Petrescu and J.K. Calautit et al., 2016c. Something about the mechanical moment of inertia. Am. J. Applied Sci., 13: 1085-1090. DOI: 10.3844/ajassp.2016.1085.1090 
Petrescu, R.V., R. Aversa, A. Apicella, F. Berto and S. $\mathrm{Li}$ et al., 2016d. Ecosphere protection through green energy. Am. J. Applied Sci., 13: 1027-1032. DOI: 10.3844 /ajassp.2016.1027.1032

Petrescu, F.I.T., A. Apicella, R.V. Petrescu, S.P. Kozaitis and R.B. Bucinell et al., 2016e. Environmental protection through nuclear energy. Am. J. Applied Sci., 13: 941-946. DOI: 10.3844/ajassp.2016.941.946

Petrescu, F.I.T. and J.K. Calautit, 2016a. About nano fusion and dynamic fusion. Am. J. Applied Sci., 13: 261-266. DOI: 10.3844/ajassp.2016.261.266

Petrescu, F.I.T. and J.K. Calautit, 2016b. About the light dimensions. Am. J. Applied Sci., 13: 321-325. DOI: 10.3844 /ajassp.2016.321.325

Petrescu, R.V., R. Aversa, B. Akash, R. Bucinell and J. Corchado et al., 2017a. Modern propulsions for aerospace-a review. J. Aircraft Spacecraft Technol., 1: 1-8. DOI: 10.3844/jastsp.2017.1.8

Petrescu, R.V., R. Aversa, B. Akash, R. Bucinell and J. Corchado et al., 2017b. Modern propulsions for aerospace-part II. J. Aircraft Spacecraft Technol., 1: 9-17. DOI: 10.3844/jastsp.2017.9.17

Petrescu, R.V., R. Aversa, B. Akash, R. Bucinell and J. Corchado et al., 2017c. History of aviation-a short review. J. Aircraft Spacecraft Technol., 1: 30-49. DOI: 10.3844 jastsp.2017.30.49

Petrescu, R.V., R. Aversa, B. Akash, R. Bucinell and J. Corchado et al., 2017d. Lockheed martin-a short review. J. Aircraft Spacecraft Technol., 1: 50-68. DOI: $10.3844 /$ jastsp.2017.50.68

Petrescu, R.V., R. Aversa, B. Akash, J. Corchado and F. Berto et al., 2017e. Our universe. J. Aircraft Spacecraft Technol., 1: 69-79. DOI: 10.3844/jastsp.2017.69.79

Petrescu, R.V., R. Aversa, B. Akash, J. Corchado and F. Berto et al., 2017f. What is a UFO? J. Aircraft Spacecraft Technol., 1: 80-90. DOI: $10.3844 /$ jastsp.2017.80.90

Petrescu, R.V., R. Aversa, B. Akash, J. Corchado and F. Berto et al., 2017g. About bell helicopter FCX-001 concept aircraft-a short review. J. Aircraft Spacecraft Technol., 1: 91-96. DOI: 10.3844/jastsp.2017.91.96

Petrescu, R.V., R. Aversa, B. Akash, J. Corchado and F. Berto et al., 2017h. Home at airbus. J. Aircraft Spacecraft Technol., 1: 97-118. DOI: $10.3844 /$ jastsp.2017.97.118

Petrescu, R.V., R. Aversa, B. Akash, J. Corchado and F. Berto et al., 2017i. Airlander. J. Aircraft Spacecraft Technol., 1: 119-148. DOI: $10.3844 /$ jastsp.2017.119.148

Petrescu, R.V., R. Aversa, B. Akash, J. Corchado and F. Berto et al., 2017j. When boeing is dreaming-a review. J. Aircraft Spacecraft Technol., 1: 149-161. DOI: $10.3844 /$ jastsp.2017.149.161

Petrescu, R.V., R. Aversa, B. Akash, J. Corchado and F. Berto et al., 2017k. About Northrop Grumman. J. Aircraft Spacecraft Technol., 1: 162-185. DOI: $10.3844 /$ jastsp.2017.162.185
Petrescu, R.V., R. Aversa, B. Akash, J. Corchado and F. Berto et al., 20171. Some special aircraft. J. Aircraft Spacecraft Technol., 1: 186-203. DOI: $10.3844 /$ jastsp.2017.186.203

Petrescu, R.V., R. Aversa, B. Akash, J. Corchado and F. Berto et al., 2017m. About helicopters. J. Aircraft Spacecraft Technol., 1: 204-223. DOI: 10.3844/jastsp.2017.204.223

Petrescu, R.V., R. Aversa, B. Akash, F. Berto and A. Apicella et al., 2017n. The modern flight. J. Aircraft Spacecraft Technol., 1: 224-233. DOI: 10.3844/jastsp.2017.224.233

Petrescu, R.V., R. Aversa, B. Akash, F. Berto and A. Apicella et al., 2017o. Sustainable energy for aerospace vessels. J. Aircraft Spacecraft Technol., 1: 234-240. DOI: 10.3844/jastsp.2017.234.240

Petrescu, R.V., R. Aversa, B. Akash, F. Berto and A. Apicella et al., 2017p. Unmanned helicopters. J. Aircraft Spacecraft Technol., 1: 241-248. DOI: $10.3844 /$ jastsp.2017.241.248

Petrescu, R.V., R. Aversa, B. Akash, F. Berto and A. Apicella et al., 2017q. Project HARP. J. Aircraft Spacecraft Technol., 1: 249-257. DOI: 10.3844 /jastsp.2017.249.257

Petrescu, R.V., R. Aversa, B. Akash, F. Berto and A. Apicella et al., 2017r. Presentation of romanian engineers who contributed to the development of global aeronautics-part I. J. Aircraft Spacecraft Technol., 1: 258-271. DOI: 10.3844 /jastsp.2017.258.271

Petrescu, R.V., R. Aversa, B. Akash, F. Berto and A. Apicella et al., 2017s. A first-class ticket to the planet mars, please. J. Aircraft Spacecraft Technol., 1: 272-281. DOI: 10.3844/jastsp.2017.272.281

Petrescu, R.V., R. Aversa, B. Akash, F. Berto and A. Apicella et al., 2017t. Forces of a 3R robot. J. Mechatronics Robotics, 1: 1-14. DOI: $10.3844 /$ jmrsp.2017.1.14

Petrescu, R.V., R. Aversa, B. Akash, F. Berto and A. Apicella et al., 2017u. Direct geometry and cinematic to the MP-3R systems. J. Mechatronics Robotics, 1: 15-23. DOI: 10.3844/jmrsp.2017.15.23

Petrescu, R.V., R. Aversa, B. Akash, F. Berto and A. Apicella et al., 2017v. Dynamic elements at MP3R. J. Mechatronics Robotics, 1: 24-37. DOI: $10.3844 / j m r s p .2017 .24 .37$

Petrescu, R.V., R. Aversa, B. Akash, F. Berto and A. Apicella et al., 2017w. Geometry and direct kinematics to MP3R with $4 \times 4$ operators. J. Mechatronics Robotics, 1: 38-46. DOI: 10.3844/jmrsp.2017.38.46

Petrescu, R.V., R. Aversa, A. Apicella, M.M. Mirsayar and S. Kozaitis et al., 2017x. Current stage in the field of mechanisms with gears and rods. J. Mechatronics Robotics, 1: 47-57. DOI: 10.3844/jmrsp.2017.47.57 
Petrescu, R.V., R. Aversa, A. Apicella, M.M. Mirsayar and S. Kozaitis et al., 2017y. Geometry and inverse kinematic at the MP3R mobile systems. J. Mechatronics Robotics, 1: 58-65. DOI: $10.3844 /$ jmrsp.2017.58.65

Petrescu, R.V., R. Aversa, A. Apicella, M.M. Mirsayar and S. Kozaitis et al., 2017z. Synthesis of optimal trajectories with functions control at the level of the kinematic drive couplings. J. Mechatronics Robotics, 1: 66-74. DOI: 10.3844/jmrsp.2017.66.74

Petrescu, R.V., R. Aversa, A. Apicella, M.M. Mirsayar and S. Kozaitis et al., 2017aa. The inverse kinematics of the plane system 2-3 in a mechatronic MP2R system, by a trigonometric method. J. Mechatronics Robotics, 1: 75-87. DOI: $10.3844 / j m r s p .2017 .75 .87$

Petrescu, R.V., R. Aversa, A. Apicella, M.M. Mirsayar and S. Kozaitis et al., 2017ab. Serial, anthropomorphic, spatial, mechatronic systems can be studied more simply in a plan. J. Mechatronics Robotics, 1: 88-97. DOI: 10.3844/jmrsp.2017.88.97

Petrescu, R.V., R. Aversa, A. Apicella, M.M. Mirsayar and S. Kozaitis et al., 2017ac. Analysis and synthesis of mechanisms with bars and gears used in robots and manipulators. J. Mechatronics Robotics, 1: 98-108. DOI: 10.3844/jmrsp.2017.98.108

Petrescu, R.V., R. Aversa, A. Apicella, M.M. Mirsayar and S. Kozaitis et al., 2017ad. Speeds and accelerations in direct kinematics to the MP3R systems. J. Mechatronics Robotics, 1: 109-117. DOI: $10.3844 /$ jmrsp.2017.109.117

Petrescu, R.V., R. Aversa, A. Apicella, M.M. Mirsayar and S. Kozaitis et al., 2017ae. Geometry and determining the positions of a plan transporter manipulator. J. Mechatronics Robotics, 1: 118-126. DOI: $10.3844 /$ jmrsp.2017.118.126

Petrescu, F.I.T., 2008. Theoretical and applied contributions about the dynamic of planar mechanisms with superior linkages. Ph.D. Thesis.

Reddy, P., K.V. Shihabudheen and J. Jacob, 2012. Precise non linear modeling of flexible link flexible joint manipulator. IReMoS, 5: 1368-1374.

Sava, I., 1970. Contributions to the optimum dynamics and synthesis of cams mechanisms. PhD Thesis, I.P.B..

Sava, I., 1971. Regarding the dynamic functioning of the internal combustion engine valve control valve. C.M. No.12., Bucharest.

Sevil, H.E. and A. Dogan, 2015. Fault diagnosis in air data sensors for receiver aircraft in aerial refueling. J. Guidance Control Dynam., 38: 1959-1975. DOI: $10.2514 / 1 . G 000527$
Sherson, J.F., H. Krauter, RK. Olsson, B. Julsgaard and K. Hammerer et al., 2006. Quantum teleportation between light and matter. Nature, 443: 557-560. DOI: 10.1038 /nature 05136

Sun, J.Z. and S.M. Joshi, 2009. An indirect adaptive control scheme in the presence of actuator and sensor failures. Proceedings of the AIAA Guidance, Navigation and Control Conference, Aug. 10-13, Chicago, Illinois. DOI: 10.2514/6.2009-5740

Tabaković, S., M. Zeljković, R. Gatalo and A. Živković, 2013. Program suite for conceptual designing of parallel mechanism-based robots and machine tools. Int. J. Adv. Robot Sys. DOI: $10.5772 / 56633$

Tang, X., D. Sun and Z. Shao, 2013. The structure and dimensional design of a reconfigurable PKM. IJARS. DOI: $10.5772 / 54696$

Tesar, D. and G.K. Matthew, 1974. The design of modelled cam sistems. Cams and cam mechanisms.

Tong, G., J. Gu and W. Xie, 2013. Virtual entity-based rapid prototype for design and simulation of humanoid robots. Int. J. Adv. Robot. Sys. DOI: $10.5772 / 55936$

Venkataraman, G., 1992. Chandrasekhar and his Limit. 1st Edn., Universities Press, ISBN-10: 817371035X, pp: 89.

Wang, K., M. Luo, T. Mei, J. Zhao and Y. Cao, 2013. Dynamics analysis of a three-DOF planar serialparallel mechanism for active dynamic balancing with respect to a given trajectory. Int. J. Adv. Robotic Sys. DOI: 10.5772/54201

Wiederrich, J.L. and B. Roth, 1974. Design of Low Vibration Cam Profiles. In: Cams and Cam Mechanisms, Rees Jones, J. (Ed.), London and Birmingham, Alabama.

Williams, D.R., 1995. Saturnian satellite fact sheet. NASA. Retrieved from: https://nssdc.gsfc.nasa.gov/planetary/factsheet/satur niansatfact.html

Wen, S., J. Zhu, X. Li, A. Rad and X. Chen, 2012. Endpoint contact force control with quantitative feedback theory for mobile robots. IJARS.

DOI: $10.5772 / 53742$

\section{Source of Figures:}

Petrescu, 2008. 